\title{
CONSTITUTIONAL PERSPECTIVES ON THE ENFORCEMENT OF SOCIO- ECONOMIC RIGHTS: RECENT SOUTH AFRICAN EXPERIENCES
}

\author{
Marius Olivier*
}

The forging of South Africa's constitution and Bill of Rights in 1996 was undoubtedly an important historic event. This paper presents a fascinating discussion concerning the treatment and methodology employed by South African Constitutional Courts in interpreting the Constitution and its Bill of Rights. Particular attention is paid to the far-reaching judgment by the Constitutional Court in Government of the Republic of South Africa v Grootboom. In concluding, this paper develops a non-exhaustive list of guiding principles developed from the Court's approach.

\section{INTRODUCTION}

The human rights abuses characteristic of the previous political dispensation in South Africa have led to the adoption of two powerful conceptual approaches when the interim and eventually the final Constitution were deliberated a few years ago: constitutionalism and the entrenchment of fundamental rights. Based on a broad consensus amongst the constitutional drafters it was accepted that these approaches were necessary in order to avoid a repeat of and to redress past injustices, on the one hand, and to forge a new culture of accommodation, mutual respect, equality and freedom in South Africa, on the other. The Preamble to the final (1996) Constitution ${ }^{1}$ bears clear testimony to this. ${ }^{2}$ And in one of its first judgments the Constitutional Court had this to say: ${ }^{3}$

* Centre for International and Comparative Labour and Social Security Law (CICLASS), Rand Afrikaans University, Johannesburg. Based on a presentation made to the New Zealand Association for Comparative Law in Wellington on 7 February 2002.

1 Preamble to the Constitution (1996).

2 "We, the people of South Africa,

Recognise the injustices of our past; 
...the Constitution introduces democracy and equality for the first time in South Africa. It acknowledges a past of intense suffering and injustice, and promises a future of reconciliation and reconstruction...

In order to give effect to the first-mentioned approach supreme status has been allocated to the Constitution: it is the supreme law of the Republic; law or conduct inconsistent with it is invalid, and the obligations imposed by it must be fulfilled. ${ }^{4}$ Constitutional supremacy has therefore effectively replaced the notion of parliamentary sovereignty, in terms of which Parliament could enact laws which discriminated against people and allowed for serious human rights abuses. ${ }^{5}$ Alongside this, as the second approach, a Bill of Rights has been enacted as part of the Constitution and specially entrenched. ${ }^{6}$ It has been made applicable to all law, and binds the executive, the judiciary and all organs of State, ${ }^{7}$ as well as natural or juristic persons, provided certain conditions

Honour those who suffered for justice and freedom in our land;

Respect those who have worked to build and develop our country; and

Believe that South Africa belongs to all who live in it, united in our diversity.

We therefore, through our freely elected representatives, adopt this Constitution as the supreme law of the Republic so as to

Heal the divisions of the past and establish a society based on democratic values, social justice and fundamental human rights;

Lay the foundations for a democratic and open society in which government is based on the will of the people and every citizen is equally protected by law:

Improve the quality of life of all citizens and free the potential of each person; and

Build a united and democratic South Africa able to take its rightful place as a sovereign state in the family of nations.

May God protect our people."

3 S v Mhlungu (1995) (3) SA 867 (CC); (1995) (7) BCLR 793 (CC) para 111.

4 The Constitution (1996), s 2.

5 See Coetzee $v$ Government of the Republic of South Africa and others; Matiso v Commanding Officer, Port Elizabeth Prison (1995) 10 BCLR 1382 (CC); 1995 (4) SA 639 (CC): "The difference between the past and the present is that individual freedom and security no longer fall to be protected solely through the vehicle of common law maxims and presumptions which neither the legislature nor the executive may abridge".

6 Bill of Rights 1996, s 74(2) signifies enhanced protection accorded to the Bill by requiring comprehensive support for its amendment: the amending Bill must be passed by the National Assembly, with a supporting vote of at least tow thirds of its members, while at least six provinces in the National Council of Provinces must cast a supporting vote. The Bill of Rights is a chapter of the Constitution (1996).

7 Bill of Rights 1996, s 8(1). 
have been met. ${ }^{8}$ The State has specifically been given the mandate to give effect to these rights, ${ }^{9}$ while an obligation has been imposed upon courts, tribunals and forums entrusted with interpreting any legislation ${ }^{10}$ to promote the spirit, purport and objects of the Bill of Rights. ${ }^{11}$

One of the major characteristics of the 1996 Constitution is the particular importance which has been attached to fundamental rights of a socio-economic nature. How the Courts have dealt with these rights, in particular in the field of social security and social protection, $^{12}$ is the subject of this contribution. The way in which these rights have played themselves out, in particular in the area of social protection, deserves special attention. Questions raised and (at least partially) answered relate to issues such as the enforceability of the rights; the nature of the obligations imposed on the State; the relationship between the various fundamental rights; the particular interpretation to be given to the fulfilment of these rights against the framework of historical injustice and present suffering; the special emphasis on the plight of exceptionally vulnerable people; and the role of actors other than the State in giving effect to these rights. However, before doing so, it might be appropriate to first consider some of salient aspects of the human rights application as this has been provided for by the Constitution and developed by the Courts.

\section{SALIENT ASPECTS OF HUMAN RIGHTS APPLICATION AND DEVELOPMENT: A CONSTITUTIONAL ENQUIRY}

\section{A Human-rights Friendly Approach}

It is clear that the South African Constitution in its Bill of Rights chapter gives extensive recognition to and entrenches not only so-called first generation (civil and political rights), both also so-called second and third generation fundamental rights (socio-economic and

8 Bill of Rights 1996, s 8(2) states: "A provision of the Bill of Rights binds a natural or a juristic person if, and to the extent that, it is applicable, taking into account the nature of the right and the nature of any duty imposed by the right."

9 Bill of Rights 1996, s 7(2) stipulates: "The state must respect, protect, promote and fulfil the rights in the Bill of Rights." As is evident from the discussion infra, certain of the fundamental rights place a specific duty on the state to realise the rights in question in a special manner.

10 Or when developing the common law or customary law.

11 Bill of Rights 1996, s 39(2).

12 Social security has to be distinguished from the wider concept of social protection. Social protection denotes a general system of basic social support which is no longer linked to the regular employment relationship, and which is founded on the conviction that society as a whole is responsible for its weaker members - in other words, a system of general welfare support and protection: B Von Maydell, "Fundamental Approaches and Concepts of Social Security" in Roger Blanpain (ed), Law in Motion (Klewer Law International, The Hague, 1997) 1029, 1034. 
environmental rights respectively), in particular in the areas of labour relations, ${ }^{13}$ environment, ${ }^{14}$ land, ${ }^{15}$ housing, ${ }^{16}$ health care, food, water, and social security, ${ }^{17}$ and with regard to children, ${ }^{18}$ education, ${ }^{19}$ language and culture rights, ${ }^{20}$ the rights of cultural, religious and linguistic communities, ${ }^{21}$ and just administrative action. ${ }^{22}$ The entrenchment of social security in a bill of rights notionally and conceptually constitutes an example of socio-economic rights protection.

The Constitution further adopts an innovative approach by placing a specific duty on the State to take positive measures in order to give effect to some of the constitutional rights, in particular the second and third generation fundamental rights. Examples include the obligation generally to perform constitutional duties, ${ }^{23}$ elevating the status and advancing the use of indigenous languages, ${ }^{24}$ respecting, protecting, promoting and fulfilling the rights in the Bill of Rights generally, ${ }^{25}$ enacting equal opportunities legislation, ${ }^{26}$ ensuring access to land on an equitable basis ${ }^{27}$ and to legally secure tenure or comparable redress, ${ }^{28}$ as well as restitution of property or equitable redress, ${ }^{29}$ access to

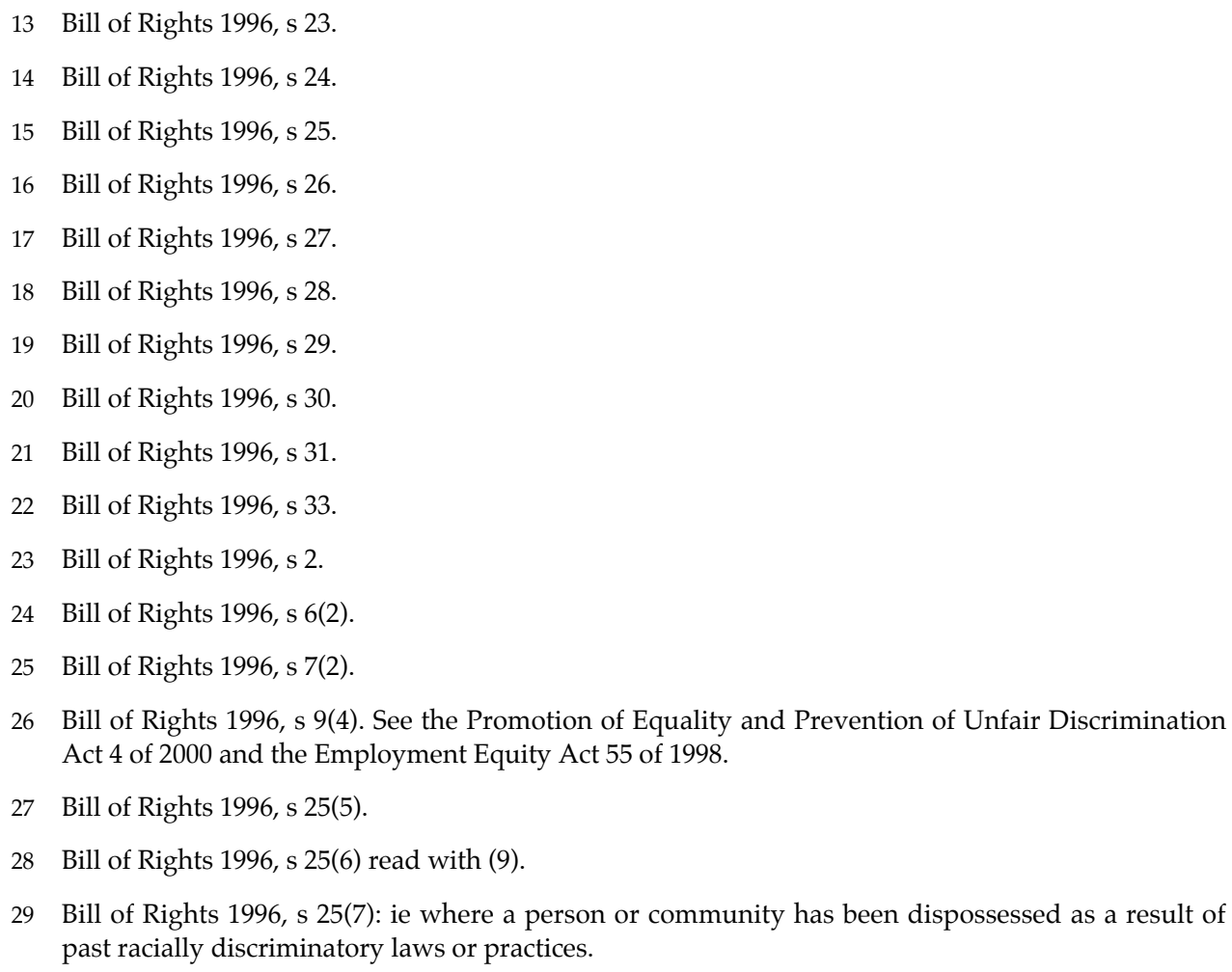

29 Bill of Rights 1996, s 25(7): ie where a person or community has been dispossessed as a result of past racially discriminatory laws or practices. 
adequate housing, ${ }^{30}$ access to health care, food, water, and social security, ${ }^{31}$ the right to further education, ${ }^{32}$ access to information held by the State, ${ }^{33}$ and just administrative action. ${ }^{34}$

The programmatic nature of giving effect to some of the rights is sometimes mentioned. In some cases a specific time frame for adopting appropriate national legislation is set. ${ }^{35}$ In other cases an obligation is placed on the State to give effect to these rights over a period of time and in programmatic fashion. This is evident from the provision requiring the State to take measures to achieve the progressive realisation of some of these rights, ${ }^{36}$ including the right to access to social security. ${ }^{37}$

When these rights and the way in which they are provided for and protected are viewed in context and as a whole, the inference can be drawn that the Constitution clearly intends to regard South Africa as a social State. This also flows from the stated aim ${ }^{38}$ to heal the divisions of the past and establish a society based on democratic values, social justice and fundamental human rights, and to improve the quality of life of all citizens and free the potential of each person. Also, the Constitutional Court has often reiterated that the meaning of the rights contained in the Bill of Rights must be determined and understood against the background of past human rights abuses, and that the Constitution endeavours to bring about reconciliation and reconstruction. ${ }^{39}$

\section{B Social Security: a Constitutional Imperative}

The constitutional entrenchment of social security rights has significantly strengthened the mandate of the State to provide comprehensive social protection. In the chapter dealing

30 Bill of Rights 1996, s 26(2). See Government of the Republic of South Africa v Grootboom (2000) 11 BCLR 1169 (CC).

31 Bill of Rights 1996, s 27(2).

32 Bill of Rights 1996, s 29(1)(a) and (b).

33 Bill of Rights 1996, s 32(2).

34 Bill of Rights 1996, s 33(3). See the Promotion of Administrative Justice Act 3 of 2000.

35 See Bill of Rights 1996, Schedule 6 item 23 (in respect of equal opportunities, access to information, and just administrative action).

36 Eg the right to have access to housing (Bill of Rights 1996, s 26(2)) and the right to have access to health care, food and water (Bill of Rights 1996, s 27(2)).

37 Bill of Rights 1996, s 27(2).

38 In the Preamble to the Constitution 1996.

39 See para 1 above and the quotation from $S v$ Mhlungu (1995) (3) SA 867 (CC). 
with the Bill of Rights the Constitution introduces a constitutional imperative whereby the government is compelled to ensure the "progressive realisation" of the right to access to social security. The Constitution grants to everyone "[t]he right to have access to social security, including, if they are unable to support themselves and their dependants, appropriate social assistance". ${ }^{40}$ It also obliges the State to implement appropriate measures: "[t]he State must take reasonable legislative and other measures, within its available resources, to achieve the progressive realisation of each of these rights". ${ }^{41}$

This is a clear and unambiguous undertaking by the drafters of the Constitution to develop a comprehensive social security system, based on, amongst others, two important paradigms: right of access for everyone and financial viability. The Constitution places an obligation on the State to ensure universal access to social security. However, the State is simultaneously allowed a certain degree of latitude in relation to three aspects: the progressive realisation of the right, the taking of reasonable measures and the availability of resources. The availability of resources is thus a factor in determining whether the State has taken reasonable measures. ${ }^{42}$ Resource constraints could be a basis for the State justifying its rate of progress in achieving the full realisation of social security rights.

When this obligation imposed on the State in terms of section 27(2) is read in conjunction with section 2 (which contains the general requirement that the obligations imposed by the Constitution must be fulfilled), the assumption can be made that the fundamental right to access to social security is enforceable, because section 2 explicitly states that duties imposed by the Constitution must be performed. This is fortified by the constitutional provision that the State must respect, protect, promote and fulfil the rights in the Bill of Rights. ${ }^{43}$ The 1997 White Paper for Social Welfare confirmed this assumption. ${ }^{44}$

40 Bill of Rights 1996, s 27(1)(c).

41 Bill of Rights 1996, s 27(2).

42 Government of the Republic of South Africa v Grootboom (2000) 11 BCLR 1169 (CC) para 46.

43 Bill of Rights 1996, s 7(2).

44 "The general long-term objective is to have an integrated and comprehensive social security system supported by the collective potential of existing social and development programmes. This would be supported by a well-informed public, which is economically self-reliant, in a country which has active labour market policies aiming at work for all, while accepting that all will not necessarily have formal employment. Where these broad goals cannot be met, social assistance should be a reliable and accessible provider of last resort. A comprehensive and integrated social security policy is needed to give effect to the Constitutional right to social security". Government Gazette "White Paper for Social Welfare" (8 August 1997) 18166 GN 1108, para 45. 


\section{An International Law - and Comparative Law-Friendly Approach}

The Constitution adopts an approach which is unashamedly international law- and comparative law-friendly. The most important provisions in this regard impacting on fundamental rights interpretation, can be found in section 39(1)(b) and (c) and section 233. A court, tribunal or forum may (but is not obliged to) consider foreign law. ${ }^{45}$ However, section 39(1)(b) stipulates that a court, tribunal or forum must, when interpreting the Bill of Rights, consider international law. According to the Constitutional Court decision in $S v$ Makwanyane, ${ }^{46}$ in the context of this provision, public international law would include nonbinding as well as binding ${ }^{47}$ law. ${ }^{48}$ International agreements and customary international law thus provide a framework within which the Bill of Rights can be evaluated and understood. In fact, there is substantial and developing jurisprudence available on the scope and core content of socio-economic rights. ${ }^{49}$ For the purpose of taking international law in consideration, decisions of other courts and tribunals dealing with comparable instruments, ${ }^{50}$ may provide guidance as to the correct interpretation of particular provisions of the Bill. Considering non-binding international law also implies that soft law must be taken into account. ${ }^{51}$ However, it has also been made clear by the Constitutional

45 Bill of Rights 1996, s 39(1)(c).

46 S v Makwanyane (1995) 3 SA 391 (CC), (1995) 6 BCLR 665 (CC) para 35, quoted with approval in The Government of the Republic of South Africa v Grootboom (2000) 11 BCLR 1169 (CC).

47 International conventions applicable to social rights that have been ratified by South Africa include the United Nations Convention on the Rights of the Child, the African Charter on Human and Peoples Rights and the African Charter on the Rights and Welfare of the Child. South Africa is in the process of ratifying the primary international document regulating social rights, namely the United Nations International Convention on Economic, Social and Cultural Rights.

48 For cases where both binding and non-binding international law was considered, see $S v$ Williams (1995) 3 SA 632 (CC); Ferreira v Levin NO (1996) 1 SA 984 (CC); S v Rens (1996) 1 SA 1218 (CC); Coetzee v Government of South Africa (1995) 4 SA 631 (CC); Bernstein v Bester (1996) 2 SA 751 (CC); In re Gauteng School Education Bill 1995 (1996) 3 SA 165 (CC); Government of the Republic of South Africa $v$ Grootboom (2000) 11 BCLR 1169 (CC) para 26.

49 Examples, hereof, are the General Comments of the United Nations Committee on Economic, Social and Cultural Rights as well as the soft law instruments referred to below.

50 Such as the United Nations Committee on Human Rights, the Inter-American Commission on Human Rights, the Inter-American Court of Human Rights, the European Commission on Human Rights, and the European Court of Human Rights, and in appropriate cases, reports of specialised agencies such as the International Labour Organisation.

51 Soft law consists of imprecise standards, generated by declarations adopted by diplomatic conferences or resolutions of international organisations, that are intended to serve as guidelines to states in their conduct, but which lack the status of "law". See Johyn Dugard International Law: A South African Perspective (Juta, Kenwyn, 2000) 157-164. Examples of soft law for purposes of social security are the Limburg Principles of 1987 and the so-called Maastricht Guidelines of 1997. These 
Court that, although the Court must take into consideration, and may be assisted by public international law, it is in no way bound to follow it. ${ }^{52}$

Furthermore, section 233 provides that "... when interpreting any legislation, every court must prefer any reasonable interpretation of the legislation that is consistent with international law over any alternative interpretation that is inconsistent with international law". Also the general limitation clause itself imports an international and comparative law friendliness in its requirement that a right "may be limited ... to the extent that the limitation is reasonable and justifiable in an open and democratic society based on human dignity, equality and freedom". ${ }^{53}$ It is, therefore, no wonder that the courts have not hesitated to invoke the provisions of international instruments when interpreting fundamental rights, including those rights which have a socio-economic character. ${ }^{54}$

\section{A Value-Based Approach}

The Preamble to the Constitution ${ }^{55}$ specifically envisages that the democratic values enshrined in the Constitution should form the basis for the establishment of a South

sources constitute official commentary by the International Commission of Jurists in co-operation with other institutions on the nature, application and duties on state parties towards the International Covenant on Economic, Social and Cultural Rights. See also the Copenhagen Declaration on Social Development and Programme of Action, adopted at the United Nations World Summit for Social Development in 1995 and renewed in 2000 (establishing a new consensus to place people at the centre of the concerns for sustainable development and pledging to eradicate poverty, promote full and productive employment, and foster social integration to achieve stable, safe and just societies for all).

52 The Government of the Republic of South Africa v Grootboom (2000) 11 BCLR 1169 (CC): "The relevant international law can be a guide to interpretation but the weight to be attached to any particular principle or rule of international law will vary. However, where the relevant principle of international law binds South Africa, it may be directly applicable". See also Prince $v$ The President of the Law Society, Cape of Good Hope (1998) 8 BCLR 976 (CC) 984-986, 988-989.

53 One of the major tests to determine "an open and democratic society based on human dignity, equality and freedom" (as required by The Constitution 1996 s 36(1)) is to embark upon a comparative study of how other open and democratic states treat similarly situated issues. In this manner, the essence of a comparative study obtains much significance.

54 See in particular Government of the Republic of South Africa v Grootboom 200011 BCLR 1169 (CC): the court referred extensively to international law instruments, especially the International Covenant on Economic, Social and Cultural Rights (ICESCR) and the General Comments of the Committee on Economic, Social and Cultural Rights (UNCESCR) for purposes of interpreting s 26(2) (limitations in respect of the right to access to housing) and s 27(2) (limitations in respect of the right to access to, amongst others, social security) and the manner in which the courts are prepared to enforce socio-economic rights.

55 Stating that the Constitution as the supreme law of the Republic aims to heal the divisions of the past and establish a society based on democratic values and to improve the quality of life of all citizens and free the potential of each person. 
African society. In various sections ${ }^{56}$ of the Constitution reference is made to fundamental values that underpin the objectives and aims of the Constitution. These values, especially in the South African context, play an important role as far as both the interpretation and the limitation of the fundamental rights are concerned. Courts, tribunals and forums are compelled by the Constitution, when interpreting the Bill of Rights, to promote the values that underlie an open and democratic society based on human dignity, equality and freedom. ${ }^{57}$ And, when considering whether a limitation of a fundamental right should pass constitutional muster, a court must be convinced, amongst others, that the limitation is reasonable and justifiable in an open and democratic society based on (the values of) human dignity, equality and freedom. ${ }^{58}$

The important role played by constitutional values in giving meaning to the socioeconomic rights embedded in the Constitution has recently been commented upon by the Constitutional Court in the seminal judgment of Government of the Republic of South Africa v Grootboom: ${ }^{59}$

There can be no doubt that human dignity, freedom and equality, the foundational values of our society, are denied those who have no food, clothing or shelter. Affording socio-economic rights to all people therefore enables them to enjoy the other rights enshrined in the Bill of Rights. The realisation of these rights is also critical to the advancement of race and gender equality and the evolution of a society in which men and women are equally able to achieve their full potential. 60

There is another most intriguing aspect of the value-based approach adopted by, in particular, the Constitutional Court. This relates to the apparent acceptance by the Court that the universal aim and basis for the existence of social rights (inclusive of social protection rights aimed at addressing exclusion and poverty) is to protect a person's right to human dignity. So much is evident from the equality jurisprudence of the Court, where the impairment or violation of a person's dignity has been elevated to a decisive criterion

56 Section 1 of the Constitution 1996 states that the Republic of South Africa is one sovereign democratic state founded on the values of human dignity, the achievement of equality and advancement of human rights and freedoms, non-racialism and non-sexism. Section 7(1) further states that the Bill of Rights is the cornerstone of democracy in South Africa. It enshrines the rights of all people in our country and affirms the democratic values of human dignity, equality and freedom.

57 The Constitution 1996, s 39(1)(a).

The Constitution 1996, s 36(1)

59 Government of the Republic of South Africa v Grootboom (2000) 11 BCLR 1169 (CC).

60 Grootboom, above, para 23. 
in cases where the unfairness of discrimination has to be proved. ${ }^{61} \mathrm{In}$ fact, the South African Courts have consistently held, also in the area of employment, that there is close correlation between the right to equality and the protection of a person's dignity. ${ }^{62}$ It could be said that the strong link between human dignity and equality is evidently in line with the purpose of social security rights, given the emphasis social security places on the eradication of poverty, vulnerability and inequalities. ${ }^{63}$ Treating human beings with dignity requires of the State to act in a reasonable manner towards those claiming social security rights, such as the right to access to housing. ${ }^{64}$ Human dignity thus as a fundamental constitutional value ${ }^{65}$ as well as a fundamental right ${ }^{66}$ contained in the Bill of Rights plays a very important role with regard to social rights pertaining to the alleviation of poverty, and the equal treatment of those who are historically deprived.

61 According to judgments such as Harksen $v$ Lane NO (1997) (6) BCLR 1489 (CC); Prinsloo v Van der Linde (1997) (6) BCLR 759 (CC); Brink v Kitschoff NO (1996) (6) BCLR 752 (CC); Jooste v Score Supermarket Trading (Pty) Ltd (1999) (2) BCLR 139 (CC) unfairness is determined by the impact of the discrimination on a person or persons in similar situations (see also E Klinck, "It Takes Three to Tango: the Right to Equality, Social Security and Constitutional Law in South Africa" (2001) 3 European Journal of Law Reform 182. Two elements are important to establish unfairness: the "listed grounds" in the Constitution and the establishment of "impact":

Under the listed or unlisted grounds one would determine whether the complainant (or group of complainants) is part of a disadvantaged or vulnerable group; whether it can/has led to patterns of harm or disadvantage; whether that is due to the group or the person's attributes and whether it impairs the person's (or group's) dignity or have a comparably serious effect.

Under the test for "impact" the person's (or group's) position in society; the nature of the discriminating provisions or power; the purpose for which the provision or power is used; the extent to which it affects the person's (or group's) rights; whether it violates the person's dignity or have a comparably serious impact; all in view of the constitutional goals.

62 Larbi-Odam $v$ Member of the Executive Council for Education (North-West Province) and the Minister of Education 919970 BCLR 1655 (CC); Hoffmann v SA Airways (2000) (21) ILJ 2357 (CC); Walters v Transitional Local Council of Port Elizabeth \& another (2001) BCLR 98 (LC).

63 Klinck, above, 182

64 Government of the Republic of South Africa v Grootboom (2000) 11 BCLR 1169 (CC) para 83: "The Constitution will be worth infinitely less than its paper if the reasonableness of state action concerned with housing is determined without regard to the fundamental constitutional value of human dignity. Section 26, read in the context of the Bill of Rights as a whole, must mean that the respondents have a right to reasonable action by the state in all circumstances and with particular regard to human dignity. In short, I emphasise that human beings are required to be treated as human beings. This is the backdrop against which the conduct of the respondents towards the appellants must be seen".

65 The Constitution 1996, ss 1 and 7(1).

66 The Constitution 1996, s 10 reads as follows: "Everyone has inherent dignity and the right to have their dignity respected and protected". 
Equally fascinating, liberal and "indigenised" is the stance taken by the Constitutional Court as regards the values to be recognised as constitutional values. The Court has adopted the approach that the range of constitutional values contained in the Constitution does not constitute a numerus clausus, and that other values can also be elevated to this status. Ubuntu or group or shared solidarity has been recognised by the Constitutional Court as such a constitutional value. ${ }^{67}$ This concept has been alluded to in the White Paper for Social Welfare ${ }^{68}$ as a value permeating the social security context as well. ${ }^{69}$ The crucial importance of this approach by the Court for the broad area of social protection and, in particular social security, is self-evident. ${ }^{70}$ Finally, all of this translates into an obligation on the State to mobilise sufficient social resources towards overcoming poverty and extreme inequalities. ${ }^{71}$ It follows that the respect for and promotion of the principle of

67 In S v Makwanyane (1995) 3 SA 391 (CC), (1995) 6 BCLR 665 (CC) ubuntu has been described as follows (para 224): "The concept is of some relevance to the values we need to uphold. It is a culture which places some emphasis on communality and on the interdependence of the members of a community. It recognises a person's status as a human being, entitled to unconditional respect, dignity, value and acceptance from the members of the community such person happens to be part of. It also entails the converse, however. The person has a corresponding duty to give the same respect, dignity, value and acceptance to each member of that community. More importantly, it regulates the exercise of rights by the emphasis it lays on sharing and coresponsibility and the mutual enjoyment of rights by all".

68 "The general long-term objective is to have an integrated and comprehensive social security system supported by the collective potential of existing social and development programmes. This would be supported by a well-informed public, which is economically self-reliant, in a country which has active labour market policies aiming at work for all, while accepting that all will not necessarily have formal employment. Where these broad goals cannot be met, social assistance should be a reliable and accessible provider of last resort. A comprehensive and integrated social security policy is needed to give effect to the Constitutional right to social security". Government Gazette "White Paper for Social Welfare" (8 August 1997) 18166 GN 1108, para 45 .

69 "The principle for caring for each other's well-being will be promoted, and a spirit of mutual support fostered. Each individual's humanity is ideally expressed through his or her relationship with others and theirs in turn through a recognition of the individual's humanity. Ubuntu means that people are people through other people". White paper, above, chapter 2 para 24.

70 An outcome of solidarity is the prevention of social exclusion, while the effort of developing social security (and other measures aimed at the alleviation of poverty and social exclusion) must therefore be accompanied by an approach aimed at promoting this crucial sense of shared responsibility - in particular between the well-off members of society and those who live in conditions of deprivation: see ILO An Introduction into Social Security (Geneva, 1984) 6-7, 115.

71 As is apparent, amongst others, from the following remark made by the Constitutional Court in the Government of the Republic of South Africa v Grootboom 200011 BCLR 1169 (CC), para 39: "A reasonable programme therefore must clearly allocate responsibilities and tasks to the different spheres of government and ensure that the appropriate financial and human resources are available". 
ubuntu can in fact guarantee the success of a comprehensive social security system and other measures aimed at the alleviation of poverty and social exclusion in South Africa.

\section{E Enforcement and Monitoring}

The Courts, in particular the Constitutional Court, fulfil a crucial role in the enforcement of fundamental rights. The Constitutional Court is the highest Court in all constitutional matters ${ }^{72}$ and may decide only constitutional matters. ${ }^{73}$ The High Court, however, may also decide on any constitutional matter except a matter that only the Constitutional Court may decide. ${ }^{74}$ For example, only the Constitutional Court may decide that Parliament or the President has failed to comply with a constitutional duty. ${ }^{75}$

As far as appropriate remedies are concerned, the Courts are empowered, whenever they decide on any issue involving the interpretation, protection and enforcement of a fundamental right contained in the Constitution, to make any order that is just and equitable ${ }^{76}$ and may grant "appropriate relief". ${ }^{77}$ Specific constitutional remedies include orders of invalidity; ${ }^{78}$ the development of the common law to give effect to the constitutional rights, ${ }^{79}$ the creation of procedural mechanisms necessary for the protection and enforcement of constitutional rights, ${ }^{80}$ and procedural remedies derived from some of the substantive rights. ${ }^{81}$

72 The Constitution 1996, s 167(7) describes a constitutional matter as any issue involving the interpretation, protection or enforcement of the Constitution.

73 The Constitution 1996, s 167(3): as well as issues connected with decisions on constitutional matters; the Constitutional Court also takes the final decision whether a matter is a constitutional matter or whether an issue is connected with a decision on a constitutional matter.

74 The Constitution 1996, s 169(1)(i).

75 The Constitution 1996, s 167(4)(e).

76 The Constitution 1996, ss 172(b) and 167(7).

77 The Constitution 1996, s 38. In Fose v Minister of Safety and Security 19973 SA 786 (CC) para 19 "appropriate relief" is described as follows: "Appropriate relief will in essence be relief that is required to protect and enforce the Constitution. Depending on the circumstances of each particular case the relief may be a declaration of rights, an interdict, a mandamus or such other relief as may be required to ensure that the rights enshrined in the Constitution are protected and enforced. If it is necessary to do so, the courts may even have to fashion new remedies to secure the protection and enforcement of these all-important rights."

78 The Constitution 1996, s 172(1)(a).

79 The Constitution 1996, ss 173 and 8(3).

80 The Constitution 1996, s 173.

81 The Constitution 1996, ss 32(10), 33(2) and 34. 
Where Parliament or the provincial legislature failed to comply with a constitutional obligation that requires positive state action the Constitutional ${ }^{82}$ or High Court $^{83}$ may grant appropriate relief. In such circumstances appropriate relief will be to make a declaratory order, where the relevant organ of State did not act in compliance with the provisions regarding the specific right. ${ }^{84}$

In addition to the Courts, there are also other institutions which are constitutionally entrusted with the task of monitoring compliance with and enforcing the constitutional fundamental rights. The Constitution grants a particularly important role to the South African Human Rights Commission (HRC) in the area of fundamental rights advocacy, promotion, and monitoring. ${ }^{85}$ This constitutional role was specifically noted by the Constitutional Court in the Grootboom judgement, ${ }^{86}$ and entails the monitoring, assessment and observance of human rights, ${ }^{87}$ as well as the power to "(a) investigate and to report on the observance of human rights; and (b) take steps to secure appropriate redress where human rights have been violated". 88 One of the most significant functions of the HRC is the evaluation of annual reports from organs of State, in order to determine to what extent these organs of State have taken measures to realise the socio-economic rights enshrined in the Constitution, in particular the rights relating to housing, health care, food, water, social security, education and the environment. ${ }^{89}$ Organs of State are compelled to submit annual reports to the Commission..$^{90}$

82 If it is non-compliance by parliament.

83 If it is non-compliance by the provincial legislature.

84 See Government of the Republic of South Africa v Grootboom (2000) 11 BCLR 1169 (CC) paras 96 and 99.

85 See The Constitution 1996, s 184(1). The Commission fulfils its constitutional mandate by undertaking research in order to produce protocols to organs of state; by submitting reports to Parliament and making them available to organs of state; by receiving individual complaints and involving itself in particular meritorious court actions (it intervened in the Grootboom above $\mathrm{n} 84$, as amicus curiae); and by monitoring compliance with the order of a Constitutional Court, for example when requested to do so by the Court (as has been the case in the Grootboom matter).

86 Grootboom, above, para 97.

The Constitution 1996, s 184(1)(c). See also the Human Rights Commission Act 1994.

The Constitution 1996, s 184(2)(a) \& (b).

The Constitution 1996, s 184(3).

90 The Constitution 1996, s 184 (3) states that "Each year, the Human Rights Commission must require relevant organs of state to provide the Commission with information on the measures that they have taken towards the realisation of the rights in the Bill of Rights concerning housing, health care, food, water, social security, education and the environment". (own emphasis) 


\section{F Limiting and Interpreting Fundamental Rights}

Fundamental rights, including the constitutional rights relating to social security, are not absolute, but may be subject to limitations of a reasonable nature. Two forms of limitation have to be considered. Firstly, the limitation must comply with the requirements contained in the (general) limitation clause (sometimes referred to as external limitations), ${ }^{91}$ bearing in mind relevant factors, some of which are explicitly mentioned in the Constitution. ${ }^{92}$ Secondly, the limitation can also be justified on the basis of the specific qualifications contained in respect of a particular right (sometimes referred to as internal limitations or qualifiers). This means, in the event of the right to access to adequate housing, or to social security, that the State is required to take reasonable measures, bearing in mind available resources, to achieve the progressive realisation of the said right. ${ }^{93}$

However, before entertaining any possible limitation of a particular fundamental right, one should first establish what the exact scope of the right is - the limitation exercise restricts itself to what is deemed to be the exact scope of the right in question. In Soobramoney $v$ Minister of Health (KwaZulu-Natal) ${ }^{94}$ the Court found that the refusal to allow a patient who suffers from chronic renal failure to make use of the facilities of a provincial hospital in KwaZulu-Natal does not amount to the refusal of "emergency medical treatment" as that term is used in section 27(3) of the Constitution. In social security terms this would also mean that the issue concerned must indeed be encapsulated by the notion

91 The Constitution 1996, s 36 adopts a three-fold test, in terms of which the limitation of a fundamental right must be: (a) in terms of a law of general application; (b) reasonable; and (c) justifiable in an open and democratic society based on human dignity, equality and freedom.

92 The relevant factors referred to in the Constitution 1996, s s 36(1)(a)-(e) are: (a) the nature of the right; (b) the importance of the purpose of the limitation; (c) the nature and extent of the limitation; (d) the relation between the limitation and its purpose; and (e) less restrictive means to achieve the purpose. See also $S v$ Makwanyane (1995) (3) SA 391 (CC) para 104; Ferreira v Levin and others; Vryenhoek and others v Powell and others (1996) (1) BCLR 1 (CC); see also D Beatty, "Constitutional Labour Rights: Pros and Cons" 199314 Industrial Law Journal (ILJ) 1.

93 The Constitution 1996, s 27(2). In Soobramoney $v$ Minister of Health (Kwazulu-Natal) (1998) (1) SA 765 (CC) Chaskalson P pronounced: "What is apparent from these provisions is that the obligations imposed on the state by ss 26 and 27 in regard to access to housing, health care, food, water and social security are dependent upon the resources available for such purposes, and that the corresponding rights themselves are limited by reason of lack of resources". (own emphasis)

94 Soobramoney, above, para 29. In the field of fundamental labour rights, in SA National Defence Union v Minister of Defence $\mathcal{E}$ another (1999) ILJ 2265 (CC), the Constitutional Court had to deal with the question whether the statutory exclusion of members of the South African Defence Force from the right to form and join trade unions, is constitutionally tenable. Even though members of the Defence Force were not employees in the normal sense of the word, they should, according to the Court, still be regarded as being covered by the fundamental right to freedom of association extended by s 23 (2) of the Constitution 1996 to "every worker". 
of "social security" or "social assistance" as used in section 27(1)(c) of the Constitution. It is to a large extent the duty of the State to develop minimum standards for defining the right to access to social security. ${ }^{95}$

When interpreting the fundamental rights, every court, tribunal and forum is required to promote particular constitutional values, and to consider international law (both binding and non-binding), while foreign law may be considered ${ }^{96}$ Fundamental rights must be interpreted purposively so as to give effect to the context, ${ }^{97}$ principles, policies and intention underlying the rights. This is certainly the view taken by the Constitution as well. ${ }^{98}$ Secondly, provision is made for principled value judgments by institutions such as the Constitutional and other Courts. ${ }^{99}$

\section{ENFORCING SOCIO-ECONOMIC RIGHTS: DRAFTING THE CONTOURS OF SOCIAL PROTECTION LAW}

\section{A The Hallmarks of Justiciability and Monitoring}

One of the vexed issues which the Constitutional Court had to grapple with when asked to certify the draft text of the 1996 Constitution, concerned the question whether these rights are generally enforceable and justiciable. ${ }^{100}$ It is sometimes argued that socio-

95 This is also the approach adopted by the South African Human Rights Commission in its first two annual Socio-Economic Rights Reports (1997-1998 and 1998-1999).

96 The Constitution 1996, s 39.

97 S v Mhlungu (1995) (3) SA 867 (CC); (1995) (7) BCLR 793 (CC) para 111: "The introduction of fundamental rights and constitutionalism in South Africa represented more than merely entrenching and extending existing common law rights, such as might happen if Britain adopted a bill of rights. The Constitution introduces democracy and equality for the first time in South Africa. It acknowledges a past of intense suffering and injustice, and promises a future of reconciliation and reconstruction...To treat it with the dispassionate attention one might give a tax law would be to violate its spirit as set out in unmistakably plain language. It would be as repugnant to the spirit, design and purpose of the Constitution as a purely technical, positivist and value-free approach to the post-Nazi constitution in Germany".

98 The Constitution 1996, s 39(3) stipulates that when interpreting any legislation, and when developing the common law, any court, tribunal or forum must promote the spirit, purport, and objects of the Bill. See also Government of the Republic of South Africa v Grootboom (2000) 11 BCLR 1169 (CC).

99 According to the Constitution 1996, s 39(1)(a) a court, tribunal or forum must, when interpreting the Bill of Rights, promote the values that underlie an open and democratic society based on human dignity, equality and freedom.

100 This question was in particular debated in the Constitutional Court first Certification judgment (Ex Parte Chairperson of the Constitutional Assembly: In Re Certification of the Constitution of the Republic of South Africa, 1996 (1996) (4) SA 744; 1996 (10) BCLR 1253 (CC) para 78) and authorities cited. 
economic rights, such as the right to social security, have to be contrasted with so-called civil and political (or first generation) rights that protect an individual against undue interference by the State (eg the right to life, ${ }^{101}$ and political rights ${ }^{102}$ ). ${ }^{103}$ Due to the peculiar nature of social security rights as socio-economic rights it is said that they cannot be enforced by the courts without intruding upon the terrain of the legislature and/or the executive branch of government.

The truth, however, is that these rights are capable of enforcement - if only the legislature or executive is ordered to take action (without necessarily prescribing the details of the action) or is sent back to the drawing board to arrange for a more equal distribution. ${ }^{104}$ The Constitutional Court is specifically empowered to decide that Parliament (or the President) has failed to comply with a constitutional duty. ${ }^{105}$ And, as indicated above, the remedies at the disposal of the Courts when deciding these issues are almost limitless.

How far will the Court go? It may require the State to review programmes and policies, ${ }^{106}$ but it is doubtful whether it will be prepared to order a specific distribution of

101 The Constitution 1996, s 11.

102 The Constitution 1996, s 19

103 The United Nations perpetuated this distinction between first, second and third generation rights by introducing two separate Covenants in 1966. The first Covenant (International Covenant on Civil and Political Rights) contains only first-generation rights and the second Covenant (International Covenant on Economic, Social and Cultural Rights) contains second and third generation rights. Underlying the decision to draft two separate Covenants was the assumption that second and third generation rights imply legal obligations and enforcement that differs substantially, from first generation rights. The same distinction is noticeable within the European regional system of human rights where a separate European Social Charter contains provisions for the realisation of economic, social and cultural rights. See Liebenberg, S "The International Covenant on Economic, Social and Cultural Rights and its Implications for South Africa" (1995) SAJHR (South African Journal of Human Rights) 359, 371-372.

104 David Beatty, "Constitutional Labour Rights: Pros and Cons" (1993) 14 Industrial Law Journal 1, 811.

105 The Constitution 1996, s 167(4)(e).

106 As happened in the Government of the Republic of South Africa v Grootboom (2000) 11 BCLR 1169 (CC) judgment, government was ordered to realign its housing programme so as to accommodate those without any form of temporary shelter, as well as in Treatment Action Campaign $\mathcal{E}$ others $v$ Minister of Health $\mathcal{E}$ others (2001) High Court, Transvaal Provincial Division, CN 21182/2001 (where government was ordered to make an anti-retroviral drug, Nevirapine, available to pregnant women with HIV who give birth in public hospitals, and their babies, in facilities where a pilot programme was not yet operational, on the condition that in the opinion of the attending medical practitioner in consultation with the medical superintendent of a clinic or hospital, it is medically indicated and the preconditions for its prescription already exist). 
financial and other sources. ${ }^{107}$ In certifying the draft text of the 1996 Constitution the Constitutional Court stressed that the socio-economic rights contained in the Constitution are justiciable, even though the inclusion of the rights may have direct financial and budgetary implications. ${ }^{108}$ Recent decisions of the Constitutional ${ }^{109}$ and the High Court ${ }^{110}$ have affirmed this position, even though the Constitutional Court has at times been relatively cautious in its approach to this issue. ${ }^{111}$ It is clear that the courts can enforce social security rights and order state organs to act positively. Where necessary, it will also

107 See the illuminating discussion by Beatty, D "Constitutional Labour Rights: Pros and Cons" 1993 14 Industrial Law Journal (ILJ) 1.

108 Ex parte Chairman of the Constitutional Assembly: In re: Certification of the Constitution of the Republic of South Africa, 1996 (1996) (4) SA 744 (CC) para 76-78. On para 77, the Court remarked: "It is true that the inclusion of socio-economic rights may result in the courts making orders which have direct implications for budgetary matters. However, even when a court enforces civil and political rights such as equality, freedom of speech and the right to a fair trial, the order it makes will often have such implications. A court may require the provision of legal aid, or the extension of state benefits to a class of people who formerly were not beneficiaries of such benefits. In our view it cannot be said that by including socio-economic rights within a bill of rights, a task is conferred upon the courts so different from that ordinarily conferred upon them by a bill of rights that it results in a breach of the separation of powers". (own emphasis)

109 "[T]hese rights are, at least to some extent, justiciable. As we have stated in the previous paragraph, many of the civil and political rights entrenched in the [constitutional text before this Court for certification in that case] will give rise to similar budgetary implications without compromising their justiciability. The fact that socio-economic rights will almost inevitably give rise to such implications does not seem to us to be a bar to their justiciability. At the very minimum, socio-economic rights can be negatively protected from improper invasion." (Government of the Republic of South Africa v Grootboom (2000) 11 BCLR 1169 (CC) para 20, quoting with approval from the judgment in Ex Parte Chairperson of the Constitutional Assembly: In Re Certification of the Constitution of the Republic of South Africa, 1996 (1996) (4) SA 744; (1996) 10 BCLR 1253 (CC) para 78.) See also the recent High Court decision of Treatment Action, above.

110 Treatment Action Campaign, above.

111 In Soobramoney $v$ Minister of Health (Kwazulu-Natal) (1998) (1) SA 765 (CC) para 29 the Court invoked the dual test of rationality and bona fides as the yardstick in this regard. It opined: "... A court must be slow to interfere with rational decisions taken in good faith by the political organs and (medical) authorities whose responsibility it is to deal with such matters". In this case the court upheld a decision by a state hospital not to provide kidney dialysis treatment to a patient because of the limited facilities available. These facilities had to be made available on a priority basis to patients who could still qualify for a kidney transplant, and not to somebody such as the applicant who was in an irreversible and final stage of chronic renal failure. See further Freedman, W "Constitutional Issues" in Olivier, M Social Security Law: General Principles (Butterworths, Durban, 1999) 519-520. Also, from other judgements in the broad area of social security, it is apparent that the Constitutional Court will not interfere easily with the underlying structure or financial balance of (publicly organised) social security schemes: cf Jooste $v$ Score Supermarket Trading (Pty) Ltd (1998) BCLR 1106 (CC) and Tsotetsi $v$ Mutual and Federal Insurance Co Ltd (1995), Constitutional Court, CN 16/95. 
allow a class action ${ }^{112}$ to be brought, in order to protect the interests of in particular the poor and vulnerable. ${ }^{113}$

In its enforcement task the Constitutional Court is supported by those constitutional institutions entrusted with monitoring compliance with the range of fundamental rights embedded in the Constitution. It is in particular the South African Human Rights Commission which plays a crucial role in this regard, as noted above. For example, in its annual reports to Parliament the Commission reflected on constitutional aspects of, amongst others, the right to access to social security. ${ }^{114}$ Also, in Grootboom the Commission, which appeared as amicus curiae in the matter, was specifically mandated with monitoring compliance with the order of the Constitutional Court and, if necessary, report in terms of its powers on the efforts made by the state to comply with the state's duties in accordance with the judgment. ${ }^{115}$ This approach effectively stresses the possibility of invoking supervisory jurisdiction. This entails that courts would give orders directing the legislative and executive branches of government to bring about reforms defined in terms

112 The Constitution 1996, s 38.

113 As happened in the Supreme Court of Appeal matter of The Permanent Secretary, Department of Welfare, Eastern Cape Provincial Government v Member of the Executive Council for Welfare, Eastern Cape Provincial Government (2001) (4) SA 1184 (SCA), where the Court commented on the institution of a class action in circumstances where disability grants were suspended unilaterally by the responsible provincial government: "The situation seemed pattern-made for class proceedings. The class the applicants represent is drawn from the very poorest within our society - those in need of statutory social assistance. They also have the least chance of vindicating their rights through the legal process. Their individual claims are small: the value of the social assistance they receive - a few hundred rands every month - would secure them hardly a single hour's consultation at current rates with most urban lawyers. They are scattered throughout the Eastern Cape Province, many of them in small towns and remote rural areas. What they have in common is that they are victims of official excess, bureaucratic misdirection and unlawful administrative methods. It is the needs of such persons, who are most lacking in protective and assertive armour, that the Constitutional Court has repeatedly emphasised must animate our understanding of the Constitution's provisions. And it is against the background of their constitutional entitlements that we must interpret the class action provision in the Bill of Rights".

114 For example, in its first two annual Socio-Economic Rights Reports (1997-1998 and 1998-1999) the Commission commented on constitutional aspects of the right to access to social security. Amongst others, it was fairly critical of the area of social assistance. It noted that the social assistance notion adopted for purposes of the Social Assistance Act 1992 is too narrow from a constitutional perspective, as it restricts the term to the income replacement grants system.

115 Government of the Republic of South Africa v Grootboom (2000) 11 BCLR 1169 (CC) para 97. 
of their objective ${ }^{116}$ and then to retain such supervisory jurisdiction as to the implementation of those reforms.

\section{B Emphasising the interrelated nature of fundamental rights: supporting a baseline approach and a dignified living}

In the Bill of the Rights no reference is made to the traditional division between first, second and third generation rights. Social rights have exactly the same status as other civil and political rights. By not differentiating between these apparent "categories" of rights the Constitution effectively endorses the notion that these rights are interrelated, interdependent and indivisible. ${ }^{117}$ The Constitutional Court made it clear that realising a particular socio-economic right, such as the right to access to housing, would require that other elements which do at times form the basis of other socio-economic rights, such as access to land, must be in place as well. Together these rights are mutually supportive and have a significant impact on the dignity of people and their quality of life: ${ }^{118}$

The right delineated in section 26(1) is a right of 'access to adequate housing' as distinct from the right to adequate housing encapsulated in the Covenant. This difference is significant. It recognises that housing entails more than bricks and mortar. It requires available land, appropriate services such as the provision of water and the removal of sewage and the financing of all of these, including the building of the house itself. For a person to have access to adequate housing all of these conditions need to be met: there must be land, there must be services, there must be a dwelling. Access to land for the purpose of housing is therefore included in the right of access to adequate housing in section 26. A right of access to adequate housing also suggests that it is not only the state who is responsible for the provision of houses, but that other agents within our society, including individuals themselves, must be enabled by legislative and other measures to provide housing. The state must create the conditions for access to adequate housing for people at all economic levels of our society. State policy dealing with housing must therefore take account of different economic levels in our society.

116 In Grootboom, above, the Court ordered (national and provincial) government to redraft its housing policy and programme in such a way as to make provision for those without any form of temporary housing.

117 Vienna Declaration and Programme of Action 1993, UN Doc A/Conf 157/23 I para 5; Guideline 4 "The Maastricht Guidelines".

118 Grootboom, above, para 35. 
In the process the Court gave an unexpectedly extensive interpretation to the notion that every person has the "right to have access to adequate housing".119 Although constitutional writers in the past viewed this as a limitation, ${ }^{120}$ in the Grootboom case the Court reached the conclusion that the "right to access to" can be interpreted broader than the "right to"; the Court effectively stressed the interrelationship between the various fundamental rights as well as the importance of access to relevant services and material resources.

When the judgement of the Court is made applicable to the area of social security, the conclusion can be reached that "access to" means more than a pure right to. ${ }^{121}$ The baseline of package approach and the emphasis on ensuring a truly dignified living also appear from the reinforcement of the right to have access to social security by other fundamental rights, such as the right to have access to health care services, ${ }^{122}$ to sufficient food and water, ${ }^{123}$ to adequate housing, ${ }^{124}$ and the right to basic education, ${ }^{125}$ as well as the right of children to basic nutrition, shelter, basic health care services and social services. ${ }^{126}$ Together these rights can be said to ensure, from a constitutional and human rights perspective, adequate social protection. ${ }^{127}$ Giving effect to one or some of them may already have an impact on the extent to or manner in which the State has to give effect to the other rights. This applies in particular to the area of social assistance. As noted by the Court in Grootboom, if under section 27 "the State has in place programmes to provide

119 Own emphasis. It should be noted that the Constitution 1996, ss 26 (the right to have access to adequate housing) and 27 (right to have access to health care services, sufficient food and water, and social security) both refer to the "right to have access to" and not purely to the "right to".

120 For example, Dennis Davis, Halton Cheadle, and Nicholas Haysom, N Fundamental Rights in the Constitution - Commentary and Cases (Juta, Kenwyn, 1997) 345 remark that the distinction can be understood as an attempt to avoid an interpretation that this section creates an unqualified obligation on the state to guarantee free housing on demand to everyone.

121 See Grootboom, above, para 35 and the accompanying text. This approach of the court places an even heavier burden on the resources of the state. It implies that the state will have to create effective policies to achieve the maximum output.

122 The Constitution 1996, s 27(1)(a).

123 The Constitution 1996, s 27(1)(b).

124 The Constitution 1996, s 26(1).

125 The Constitution 1996, s 29(1).

126 The Constitution 1996, s 28(1)(c).

127 There are, of course, also other fundamental rights, which evidently play a significant role in the context of South African social security, such as the right to equality (the Constitution 1996, s 9), the right to privacy (he Constitution 1996, s 14), the right to property (the Constitution 1996, s 25) and the right to just administrative action (the Constitution 1996, s 33). 
adequate social assistance to those who are otherwise unable to support themselves and their dependants, that would be relevant to the State's obligations in respect of other socioeconomic rights". 128

\section{Negative and positive obligations: the duty to respect, protect, promote and fulfil}

On the basis of the wording of section $7(2)$, referring to the obligation on the State to respect, protect, promote and fulfil the fundamental rights contained in chapter 2 of the Constitution, a broad distinction is drawn between negative duties and positive duties imposed on the State. The duty to respect essentially entails negative state action, requiring of the State not to interfere unduly. The duties to protect, promote, and fulfil places a positive duty on the State and may require positive action from the courts. ${ }^{129}$

On a primary level the duty to respect requires negative state action and the Courts will only expect the State not to unjustly interfere with a person's fundamental rights. ${ }^{130}$ This is known as negative enforcement by the Courts. In the area of social security this would, amongst others, entail that the State should allow individuals to insure themselves against particular contingencies. In Grootboom the Constitutional Court remarked, within the context of the right to access to adequate housing, ${ }^{131}$ that there is, at the very least, a negative obligation placed upon the State and all other entities and persons to desist from preventing or impairing the right of access to adequate housing. ${ }^{132} \mathrm{~A}$ similar finding was made by the High Court with regard to the right to health care, ${ }^{133}$ in view of the refusal on

128 Government of the Republic of South Africa v Grootboom (2000) 11 BCLR 1169 (CC) para 36.

129 See generally Ex parte Chairman of the Constitutional Assembly: In re: Certification of the Constitution of the Republic of South Africa, 1996 (1996) (4) SA 744 (CC) para 20. K O'Regan, "Introducing Socioeconomic Rights" (1999) Economic and Social Rights Review 2 also suggests another (ie a fourth) level of obligation: a right may place an obligation on the State to act rationally and in good faith, and require that it justifies its failure to carry out its obligations. In other words, there must be a good reason for the State not to respect, protect, promote, and fulfil a right.

130 Maastricht Guidelines on Violations of Economic, Social and Cultural Rights para II para 6; O'Regan, above, 2. However, positive action may be required where interference with a fundamental right has taken place: sufficient remedies should be provided by the State to deal with such interference. See also Ex parte Chairman of the Constitutional Assembly: In re: Certification of the Constitution of the Republic of South Africa, 1996 (1996) (4) SA 744 (CC) para 20.

131 The Constitution 1996, s 26(1).

132 Government of the Republic of South Africa v Grootboom (2000) 11 BCLR 1169 (CC) para 34. In the same parathe Court further remarked: "The negative right is further spelt out in subsection (3) [of section 26 of the Constitution] which prohibits arbitrary evictions."

133 The Constitution 1996, s 27(1)(a). 
the part of the South African government to provide the anti-retroviral drug, Nevirapine, country-wide to HIV-positive pregnant women through the State hospital system. ${ }^{134}$

On a secondary level all fundamental rights require the State to protect citizens from political, economic and social interference with their stated rights. ${ }^{135}$ It places a positive obligation on the State not to interfere in the fundamental rights of its citizens. This obligation does not, as such, require that the State distribute money or resources to individuals, but requires setting up a framework wherein individuals can realise these rights without undue influence from the State. It requires in particular that the State protects especially vulnerable groups, and includes protection against third (non-State) party violations of these rights. Practically this would, in the field of social security, for example, mean that pensions, medical insurance and unemployment insurance legislation should be construed in such a manner that they sufficiently protect individuals against discrimination in acquiring benefits. In some $\operatorname{cases}^{136}$ the right to just administrative action $^{137}$ has been used to protect people's social security rights. It is in particular in the area of social assistance that the administrative law principles of natural justice, underpinned by the constitutional imperative in this regard, have contributed significantly

134 Treatment Action Campaign \& others $v$ Minister of Health \& others (2001) High Court, Transvaal Provincial Division, CN 21182/2001 the Court indicated that the breach can be remedied by ordering government to adopt certain positive measures, namely to make available the drug on a country-wide basis through the public hospital system and to formulate an effective comprehensive national programme to prevent mother to child transmission of HIV on a national basis. However, the Court also stressed that the drug only has to be made available in public health facilities where in the opinion of the attending medical practitioner in consultation with the medical superintendent of a clinic or hospital, it is medically indicated and the preconditions for its prescription already exist.

135 Maastricht Guidelines on Violations of Economic, Social and Cultural Rights para II para 6; K O'Regan, "Introducing Socio-economic Rights" (1999) Economic and Social Rights Review 2.

136 For example, in the case of Tseleng $v$ The Chairman, Unemployment Insurance Board \& another (1995) (4) LCD 139 (T); (1995) (16) ILJ 830 (T) the Court was asked to review the policy of the Unemployment Insurance Board in terms whereof the granting of additional benefits (as provided for by s 35 of the Unemployment Insurance Act 1966) was made subject to the requirement that the applicant must satisfy the Board that he or she actively sought work while receiving initial unemployment benefits. Amongst other things, the Court found the policy to be unconstitutional, due to the fact that the policy had not been disclosed to the applicant. The failure to disclose the policy amounted to a breach of the applicant's fundamental right to procedurally fair administrative action conferred by s 24 of the Constitution 1996 (at $845 \mathrm{E}-\mathrm{G}$ ).

137 The Constitution 1996, s 33. 
to the protection of the rights and interests of those dependant on state support, against arbitrary and unlawful State action. ${ }^{138}$

At tertiary level section 7(2) requires that the state promote and fulfil everyone's rights. ${ }^{139}$ The beneficiary has the right to require positive assistance, or a benefit or service from the State. The nature and scope of these obligations placed on the State depends on the exact wording or phrasing of the fundamental right as well as on the internal and external limitations of this right, and the relationship with other fundamental rights. ${ }^{140}$ "Promotion" means that the relevant legislative, executive and judicial frameworks for the realisation of, for example, the right to access to social security, have to be both in place and effective. "Fulfilment" in this context means to provide opportunities for individuals or associations to realise the right and/or to provide for the fulfilment of the right by directly providing for the need, for example by making available resources for the acquisition thereof. For example, in the Grootboom case the Constitutional Court found that the State has a duty to provide emergency housing (ie shelter) to particularly needy and vulnerable groups of persons, should they not be able to provide in this for themselves.

$D$ Qualifying the Obligations and Focusing the Attention on the Particularly Vulnerable: Reasonable Measures, Available Resources and Progressive Implementation

Sections 26(2) (relating to the right to access to adequate housing) and 27(2) (relating to the right to access to, inter alia, social security) provide that the State must take reasonable

138 Mbanga v MEC for Welfare (2001) 8 BCLR 821 (SE) and Nomala v Permanent Secretary, Department of Welfare (2001) 8 BCLR 844 (E) (the State-provided social assistance grant must be made within a reasonable time of application). In other cases the Courts emphasised that the unilateral withdrawal or suspension of grants without proper adherence to the administrative law principles of natural justice and the rights which had accrued in terms of statute, is unlawful and invalid: Bacela $v$ MEC for Welfare (Eastern Cape Provincial Government) (1998) (1) All SA 525 (E); Ngxuza $\mathcal{E}$ others $v$ Secretary, Department of Welfare, Eastern Cape Provincial Government $\mathcal{E}$ another (2000) BCLR 1322 (E); Bushula $\mathcal{E}$ others v Permanent Secretary, Department of Welfare, Eastern Cape Provincial Government $\mathcal{E}$ another (2000) BCLR 728 (E); Rangani v Superintendent-General, Department of Health and Welfare, Northern Province (1999) (4) SA 385 (T); and Mpofu v MEC for the Department of Welfare and Population Development in Gauteng Provincial Government (18 February 2000), WLD 2848/99. The Ngxuza judgment has recently been upheld by the Supreme Court of Appeal: The Permanent Secretary, Department of Welfare, Eastern Cape Provincial Government v Member of the Executive Council for Welfare, Eastern Cape Provincial Government (2001) (4) SA 1184 (SCA).

139 Maastricht Guidelines on Violations of Economic, Social and Cultural Rights para II para 6; O'Regan, K "Introducing Socio-economic Rights" (1999) Economic and Social Rights Review 2.

140 As is discussed in more detail below with reference to Government of the Republic of South Africa $v$ Grootboom (2000) 11 BCLR 1169 (CC) para 34. Internal limitations are limitations contained within the fundamental right self and are aimed to confine the scope and application of the specific fundamental right. External limitations refer to the general limitation clause in the Bill of Rights (s 36). 
legislative and other measures, within its available resources, to achieve the progressive realisation of each of these rights. The meaning attached to these notions has been commented on in several judgments, in particular in Government of the Republic of South Africa $v$ Grootboom, ${ }^{141}$ and sheds light on the manner in which the Courts are prepared to enforce socio-economic rights. ${ }^{142}$

Reasonable legislative and other measures In Grootboom the Constitutional Court confirmed: (a) a principled non-interventionist approach on the part of the court, so long as (b) the measures adopted are reasonable, ${ }^{143}$ (c) both in their conception and implementation (in particular as far as the programmes in place are concerned). ${ }^{144}$ However, in Soobramoney $v$ Minister of Health (KwaZulu-Natal $)^{145}$ no mention was made of reasonableness, as emphasis was placed on rationality and bona fides as the appropriate yardsticks. ${ }^{146}$ In its interpretation of similarly worded provisions of the International Covenant on Economic, Social and Cultural Rights ${ }^{147}$ the responsible United Nations Committee (the UNCESCR $)^{148}$ has been of the opinion that if the State is a developing country, or is experiencing economic difficulties, it must at least realise the so-called "minimum core obligations". ${ }^{149}$ However, in Grootboom the Constitutional Court found the

141 Grootboom, above.

142 This case deals with the state's obligations under s 26 of the Constitution 1996, which grants to everyone the right of access to adequate housing.

143 Grootboom, above, para 41: "A court considering reasonableness will not enquire whether other more desirable or favourable measures could have been adopted, or whether public money could have been better spent. The question would be whether the measures that have been adopted are reasonable. It is necessary to recognise that a wide range of possible measures could be adopted by the State to meet its obligations. Many of these would meet the requirement of reasonableness. Once it is shown that the measures do so, this requirement is met".

144 See also Treatment Action Campaign $\mathcal{E}$ others $v$ Minister of Health $\mathcal{E}$ others (2001) High Court, Transvaal Provincial Division, CN 21182/2001.

145 Soobramoney $v$ Minister of Health (KwaZulu-Natal) (1997) 12 BCLR 1696 (CC) para 29.

146 The Court held that it would be slow to interfere with rational decisions taken in good faith by the political organs and medical authorities whose responsibility it is to deal with such matters. It made it clear that the Court will be reluctant to interfere with the functions of the legislative and executive branches of government. The State thus has a discretion as to when and how these rights should be realised.

147 International Covenant on Economic, Social and Cultural Rights, Art 2(1), which requires that State parties must realise the rights contained in the Covenant to the "maximum of their available resources".

148 The United Nations Committee on Economic, Social and Cultural Rights (UNCESCR). 
investigation into minimum core obligations to be inapplicable in the South African context, ${ }^{150}$ and opted for an approach in terms whereof merely the reasonableness of the measures is evaluated.

Grootboom also emphasised that regard must be had to the extent and impact of historical disadvantage, the need to ensure that basic necessities of life are available to all, and the importance of not neglecting particularly vulnerable groups. The Court remarked: 151

Reasonableness must also be understood in the context of the Bill of Rights as a whole. A society must seek to ensure that the basic necessities of life are provided to all if it is to be a society based on human dignity, freedom and equality. To be reasonable, measures cannot leave out of account the degree and extent of the denial of the right they endeavour to realise. Those whose needs are the most urgent and whose ability to enjoy all rights therefore is most in peril, must not be ignored by the measures aimed at achieving realisation of the right. It may not be sufficient to meet the test of reasonableness to show that the measures are capable of achieving a statistical advance in the realisation of the right. Furthermore, the Constitution requires that everyone must be treated with care and concern. If the measures, though statistically successful, fail to respond to the needs of those most desperate, they may not pass the test.

Progressive realisation With reference to the interpretation accorded to the slightly differently worded ${ }^{152}$ article 2(1) of the International Covenant on Economic, Social and

149 "The Committee is of the view that a minimum core obligation to ensure the satisfaction of, at the very least, minimum essential levels of each of the rights is incumbent upon every State Party": General Comment No 3, 86 para 10. In its first annual report submitted to Parliament the South African Human Rights Commission also remarked that minimum standards for defining the right to access to social security must still be developed.

150 The Court noted that the General Comment of the UNCESCR does not specify precisely what the content of the minimum core obligations is (para 30). The Court further stressed that the minimum core obligation is determined generally by having regard to the needs of the most vulnerable group that is entitled to the protection of the right in question. It is in this context that the concept of minimum core obligation must be understood in international law (para 31). The Court argued that it is not possible to determine the minimum threshold for South African purposes due to the fact that the Court does not have comparable information like the UNCESCR. It referred to the fact the UNCESCR developed the concept of minimum core over many years of examining reports by reporting states (para 32). It further indicated that it is not in any event necessary to decide whether it is appropriate for a court to determine in the first instance the minimum core content of a right (para 33).

151 Grootboom, above, para 44.

152 The ultimate objective of the Covenant is the "full realisation" of the rights enshrined in the Covenant, while ss 26(2) and 27(2) of the South African Constitution 1996 merely require that the 
Cultural Rights, ${ }^{153}$ the Court in Grootboom applied the interpretation given by the United Nations Committee on Economic, Social and Cultural Rights (UNCESCR) to the meaning of this phrase. The Court stated that "progressive realisation" shows that it was contemplated that the right could not be realised immediately, but the goal of the Constitution is that the basic needs of all in our society be effectively met and the requirement of progressive realisation means that the State must take steps to achieve this goal. ${ }^{154}$ It continued: ${ }^{155}$

It means that accessibility should be progressively facilitated: legal, administrative, operational and financial hurdles should be examined and, where possible, lowered over time. Housing must be made more accessible not only to a larger number of people but to a wider range of people as time progresses.

This translates into an obligation to roll out a realistic and comprehensive plan or programme as to how, when and by what means the fundamental right in question is to be given effect to in progressive fashion. It was the very lack of a sufficiently comprehensive plan which caused the Constitutional Court in Grootboom and the High Court in the Treatment Action Campain case to rule that government has not complied with its constitutional duties in this regard.

Within the available resources In Soobramoney $v$ Minister of Health (KwaZulu-Natal) ${ }^{156}$ the Constitutional Court ruled that the relevant socio-economic rights are qualified by the "available resources" restriction; there is no unqualified obligation to meet existing needs. ${ }^{157}$ Limited resources may, therefore, justify giving priority to the larger needs of

State must "achieve the progressive realisation of each of these rights" and not the full realisation of these rights.

153 The United Nations Committee on Economic, Social and Cultural Rights (UNESCR) summarised the position as follows: "On the other hand, the phrase must be read in the light of the overall objective, indeed the raison d'etre, of the Covenant which is to establish clear obligations for State parties in respect of the full realisation of the rights in question. It thus imposes an obligation to move as expeditiously and effectively as possible towards the goal." (General Comment No 3, 85 para 9). It further remarked that "any deliberately retrogressive measures ... would require the most careful consideration and would need to be fully justified by reference to the totality of the rights provided for in the Covenant and in the context of the full use of the maximum of available resources".

154 Grootboom, above, para 45.

155 Grootboom, above.

156 In Soobramoney $v$ Minister of Health (KwaZulu-Natal) 199712 BCLR 1696 (CC).

157 "What is apparent from these provisions is that the obligations imposed on the state by sections 26 and 27 in regard to access to housing, health care, food, water and social security are dependent upon the resources available for such purposes, and that the corresponding rights themselves are 
society, rather than the specific needs of particular individuals. ${ }^{158}$ This appears to be the impact of the Grootboom judgment ${ }^{159}$ as well, as government was ordered to make provision in its housing programme for the extremely vulnerable.

In Grootboom ${ }^{160}$ the Court also stressed that there is a balance between goal and means. The measures must be calculated to attain the goal expeditiously and effectively but the availability of resources is an important factor in determining what is reasonable.

\section{E Multi-actor Responsibility}

It is evident that government, in particular national government, is not in a position to realise the socio-economic rights enshrined in the Constitution on its own. ${ }^{161}$ Three issues need to be raised. Firstly, in particular in those cases where the Constitution foresees concurrent national and provincial jurisdictional competence, such as housing and welfare services, ${ }^{162}$ the position is that the task of adopting reasonable measures is a function which is shared by the different tiers of government. The Constitutional Court commented:

What constitutes reasonable legislative and other measures must be determined in the light of the fact that the Constitution creates different spheres of government: national government, provincial government and local government. ${ }^{163}$ The last of these may, as it does in this case, comprise two tiers. 164 The Constitution allocates powers and functions amongst these different spheres emphasising their obligation to co-operate with one another in carrying out

limited by reason of the lack of resources. Given this lack of resources and the significant demands on them that have already been referred to, an unqualified obligation to meet these needs would not presently be capable of being fulfilled. This is the context within which section 27(3) must be construed". (Soobramoney, above, para 11 - as quoted with approval in Grootboom, above, para 46).

158 "The state has to manage its limited resources in order to address all these claims. There will be times when this requires it to adopt a holistic approach to the larger needs of society rather than to focus on the specific needs of particular individuals within society": Soobramoney, above, para 46.

159 Grootboom, above.

160 Grootboom, above, para 46.

161 "A right of access to adequate housing also suggests that it is not only the state who is responsible for the provision of houses, but that other agents within our society, including individuals themselves, must be enabled by legislative and other measures to provide housing": Grootboom, above, para 35 .

162 See Schedule 4 of the Constitution, 1996.

163 See Chapter 3 of the Constitution, 1996.

164 See ss 155(1)(b) and (c) of the Constitution as well as s 7(1)(b), read with ss 10B and 10C, of the Local Government Transition Act 1993. 
their constitutional tasks. In the case of housing, it is a function shared by both national and provincial government. Local governments have an important obligation to ensure that services are provided in a sustainable manner to the communities they govern. ${ }^{165} \mathrm{~A}$ reasonable programme therefore must clearly allocate responsibilities and tasks to the different spheres of government and ensure that the appropriate financial and human resources are available. ${ }^{166}$

Thus, a co-ordinated State housing programme must be a comprehensive one determined by all three spheres of government in consultation with each other as contemplated by Chapter $3^{167}$ of the Constitution.... Each sphere of government must accept responsibility for the implementation of particular parts of the programme but the national sphere of government must assume responsibility for ensuring that laws, policies, programmes and strategies are adequate to meet the state's section 26 obligations. In particular, the national framework, if there is one, must be designed so that these obligations can be met. It should be emphasised that national government bears an important responsibility in relation to the allocation of national revenue to the provinces and local government on an equitable basis. ${ }^{168}$ Furthermore, national and provincial government must ensure that executive obligations imposed by the housing legislation are met. ${ }^{169}$

However, it was also made clear that national government bears the overall responsibility for ensuring that the State complies with its constitutional obligations. ${ }^{170}$

Secondly, the State's duty to realise the right in question may differ according to whether the ability of those affected to realise the right is absent or not. Where the ability to afford, for example, to pay for adequate housing exists, the State's primary obligation is not that of direct provider, but of "unlocking the system, providing access to housing stock and a legislative framework to facilitate self-built houses through planning laws and access to finance". ${ }^{171}$ For those who cannot afford to pay, "[I]ssues of development and social welfare are raised". ${ }^{172}$ This was forcefully brought home in a subsequent judgement of the

165 See the Constitution 1996 s 152(1)(b), read with ss 152(2) and 153(a).

166 Government of the Republic of South Africa v Grootboom (2000) 11 BCLR 1169 (CC) para 39.

167 The chapter dealing with co-operative governance.

168 See s 214 of the Constitution 1996, and, in particular, ss 214(2)(d) and (f).

169 See ss 100, 139 and 155(7) of the Constitution 1996 and Government of the Republic of South Africa v Grootboom (2000) 11 BCLR 1169 (CC) para 40.

170 Grootboom, above, para 66.

171 Grootboom, above, para 36.

172 Grootboom, above. 
Constitutional Court, where it was assumed that flood victims left homeless have a constitutional right to be provided with access to housing. ${ }^{173}$ The point is that State policy needs to address both these groups, and that the poor are particularly vulnerable and that their needs, therefore, require special attention. ${ }^{174}$

The same principled approach has been adopted by the Court as far as the rights of children are concerned. Section 28(1)(c) of the Constitution creates the right of children to basic nutrition, shelter, basic health care services and social services. However, unlike the right to have access to adequate housing or to social security, these rights have not been made subject to the "reasonable measures", "available resources" and "progressive realisation" qualifiers. And yet the Constitutional Court was not prepared to find that the State bears the primary responsibility to give effect to children's rights, and has to do so despite the availability of resources and in an immediate fashion. It noted that the section does not create separate and independent rights for children and their parents. ${ }^{175}$ The State's obligations, emanating from its international obligations, ${ }^{176}$ require of the State to take steps to ensure that children's rights are observed: "In the first instance, the State does so by ensuring that there are legal obligations to compel parents to fulfil their responsibilities in relation to their children'. ${ }^{177}$

Hence, to the Court argued, a proper construction of section 28 implies that "a child has the right to parental or family care in the first place, and the right to alternative

173 Minister of Public Works $\mathcal{E}$ others v Kyalami Ridge Environmental Association E another (29 May 2001) Constitutional Court, CN 55/00, para 26. In this matter the Court had to deal with the erection of temporary transit housing on state land for the said victims. The Court concluded: "This was an essential national project implemented in terms of a policy decision taken by government that called for a co-ordinated effort by different spheres of government and the application of substantial funds. The provision of relief to the victims of natural disasters is an essential role of government in a democratic state, and government would have failed in its duty to the victims of the floods, if it had done nothing. There was no legislation that made adequate provision for such a situation, and it cannot be said that in acting as it did, government was avoiding a legislative framework prescribed by parliament for such purposes. Nor can it be said that government was acting arbitrarily or otherwise contrary to the rule of law. If regard is had to its constitutional obligations, to its rights as owner of the land, and to its executive power to implement policy decisions, its decision to establish a temporary transit camp for the victims of the flooding was lawful. "(para 52)

174 Kyalami Ridge, above.

175 Grootboom, above, para 74.

176 In terms of the Convention on the Rights of the Child (General Assembly Resolution 44/25 of 20 November 1989). The Convention entered into force on 2 September 1990, was signed by South Africa on 29 January 1993 and ratified on 15 December 1995.

177 Grootboom, above, para 75 . 
appropriate care only where that is lacking. Through legislation and the common law, the obligation to provide shelter in subsection (1)(c) is imposed primarily on the parents or family and only alternatively on the State. The State thus incurs the obligation to provide shelter to those children, for example, who are removed from their families. It follows that section 28(1)(c) does not create any primary State obligation to provide shelter on demand to parents and their children if children are being cared for by their parents or families". ${ }^{178}$

And, thirdly, so the Court stressed, effective implementation requires at least adequate budgetary support by national government. ${ }^{179}$ It is essential that a reasonable part of the national housing budget be devoted to granting relief to those in desperate need; however, the precise allocation is for national government to decide in the first instance. ${ }^{180}$

\section{CONCLUSIONS}

In summary then, it would appear that the following conclusions can be drawn from the approach of the courts when enforcing socio-economic rights. These represent a nonexhaustive list of important elements of and guiding principles emanating from some of the judgments in the area of socio-economic rights, within the context of social security and social protection.

(a) The power of the courts to interfere and remedies at the disposal of the courts Courts have the power to enforce socio-economic rights and in particular the right to access to social security and other social security related rights. Wide-ranging remedies are

178 Grootboom, above, para 77. The Court went to great lengths in explaining what the duties of the state are where children are cared for by their parents and families: "This does not mean, however, that the state incurs no obligation in relation to children who are being cared for by their parents or families. In the first place, the state must provide the legal and administrative infrastructure necessary to ensure that children are accorded the protection contemplated by section 28 . This obligation would normally be fulfilled by passing laws and creating enforcement mechanisms for the maintenance of children, their protection from maltreatment, abuse, neglect or degradation, and the prevention of other forms of abuse of children mentioned in section 28. In addition, the state is required to fulfil its obligations to provide families with access to land in terms of section 25, access to adequate housing in terms of section 26 as well as access to health care, food, water and social security in terms of section 27. It follows from this judgment that sections 25 and 27 require the state to provide access on a programmatic and coordinated basis, subject to available resources. One of the ways in which the state would meet its section 27 obligations would be through a social welfare programme providing maintenance grants and other material assistance to families in need in defined circumstances". (para 78)

179 Grootboom, above, para 68.

180 Grootboom, above, para 66. 
at the disposal of the courts in this regard. This may result in courts making orders, which have direct implications for budgetary matters. ${ }^{181}$

(b) A comprehensive and integrated approach required The Constitutional Court has affirmed that all the rights contained in the Bill of Rights are interrelated and mutually supporting. ${ }^{182}$ It is, therefore, not sufficient to attempt to adopt measures which give effect to the right to access to social security in isolation. In concrete terms this implies that when developing the social security system the State must ensure that: (a) all related constitutional values and rights, such as human dignity, freedom and equality, be given effect to; and (b) access is granted to resources which are necessary for the realisation of the right to access to social security and other related rights, with particular reference to food, clothing and shelter and, where appropriate, land. Provision of adequate (which could be basic) support must be made available to those in need as a matter of priority.

(c) The need for a policy-based programme and legislative implementation The Constitution requires the devising, formulation, funding and implementing, as well as the constant review, within the resources available, of a comprehensive and co-ordinated programme with well-targeted policies. These have to be reasonable both in their conception and their implementation, and must be implemented by the executive and through legislative intervention. ${ }^{183}$ Provided that the measures adopted are reasonable, the Constitutional Court will generally speaking also uphold a social security programme, which institutionalises social security provision.

(d) A range of reasonable measures at the disposal of government and the legislature As long as the measures aimed at developing the social security system are reasonable in their conception and implementation, the Courts will not consider whether other more desirable or favourable measures could have been adopted or whether public money could have been better spent. ${ }^{184}$ There is also some indication that the Courts will not interfere with rational decisions (on budgets) taken in good faith. ${ }^{185}$ A wide range of available options may, therefore, be considered and adopted by the State. The measures adopted

181 In re the Certification of the Constitution of the Republic of South Africa 1996 (1996) (10) BCLR 1253 (CC) para 77.

182 Grootboom, above, para 53.

183 Grootboom, above, para 42.

184 Grootboom, above, para 41.

185 Soobramoney $v$ Minister of Health, Kwa-Zulu Natal (1998) (1) SA 765 (CC); 1997 (12) BCLR 1696 (CC) para 29. 
may, subject to the constraints of the equality right, differentiate on the basis of past exclusion and disadvantage, and on the basis of socio-economic status. ${ }^{186}$

(e) Allocating responsibilities and empowering implementing and delivery institutions A reasonable programme must clearly allocate responsibilities and tasks and ensure appropriate financial and human resources. ${ }^{187}$ This does not only apply to the various spheres of government (national, provincial and local), but also to non-governmental organisations and other private providers. The responsibility in the areas of social security implementation and service delivery is shared not only by State institutions at the various levels, but also by other agents within society, including individuals themselves. They must be enabled by legislative and other measures to provide housing. National government bears the overall responsibility for ensuring that the State complies with its constitutional obligations. ${ }^{188}$

(f) Sufficient budgetary support required While courts will be hesitant to interfere in budgetary provision in the area of social security, the Constitutional Court indicated in its certification judgement, as noted above, that Courts could grant orders which may have budgetary implications. In Grootboom the Constitutional Court stressed, within the context of the right to access to housing, that effective implementation requires at least adequate budgetary support by national government. ${ }^{189}$ It emphasised that it is essential that a

186 On the basis of the judgments in Soobramoney, above, Grootboom, above and Treatment Action Campaign $\mathcal{E}$ others $v$ Minister of Health $\mathcal{E}$ others (2001) High Court, Transvaal Provincial Division, CN 21182/2001 and the relevant international law principles the reasonableness of the measures will be evaluated against criteria such as:

- The social, economic and historical context of the deficiencies in the system the measures aim to address;

- The institutional capacity to implement the programme adopted;

- Whether the programme is balanced, flexible and open to review, and makes appropriate provision for attention to the deficiencies in the system and to short-, medium- and longterm needs;

- Whether the programme is inclusive and does not exclude a significant segment of society;

- Whether the measures ensure that basic human needs are met and takes into account the degree and extent of the denial of the right they endeavour to realise; and

- Whether the programme and measures ensure that a larger number of people and a wider range of people as time progresses benefit from them.

187 Grootboom, above, para 39.

188 Grootboom, above, para 66.

189 Grootboom, above, para 68. 
reasonable part of the national housing budget be devoted to granting relief to those in desperate need, but that the precise allocation is for national government to decide in the first instance. ${ }^{190}$ Guidelines drawn up in the wake of budget constraints have to be reasonable. ${ }^{191}$

(g) The constitutional focus on vulnerable groups Provision has to be made for the most vulnerable and desperate in society. ${ }^{192}$ The courts may or may not be hesitant to grant relief where individuals assert their constitutional rights. However, where communities are negatively affected, and the right infringed is fundamental to the wellbeing of (categories of) people (such as housing), the Constitutional Court appears to be more willing to intervene. This is in particular the case where the said communities have historically been marginalised and/or excluded or appear to be particularly vulnerable. A statistical advance may not be enough and the needs that are the most urgent must be addressed; it is not only the State that is responsible for the provision of (for example) houses, but it may be held responsible if no other provision has been made or exists. ${ }^{193}$ This does, of course, imply priority-setting.

(h) The inadvisability of retrogressive measures In keeping with the principles set out above, as well the views adopted in respect of the provisions of the International Covenant on Economic, Social and Cultural Rights, ${ }^{194}$ retrogressive measures (such as the phasing out or downscaling of a particular social security scheme or grant) are prima facie incompatible with the obligation to progressively realise the right to (access to) social security and social assistance. Any such reduction or downscaling will be subject to the courts' careful consideration. Of course, it remains possible to adopt replacement programmes, which provide, at the least, the same or similar standard of living.

That the South African Constitutional Court has embarked upon an innovative and fascinating route of developing an original and ambitious constitutional jurisprudence in the area of socio-economic rights, is beyond doubt. That it will result in a sense of human dignity experienced by and the comprehensive improvement in the quality of lives of so many who are marginalised and impoverished is to be trusted. This, one is tempted to

190 Grootboom, above, para 66.

191 Soobramoney, above, para 25.

192 Grootboom, above, paras 52 and 69, where the failure to make express provision to facilitate access to temporary (housing) relief for people who have no access to land, no roof over their heads or who live in intolerable conditions was found to fall short of the obligation set by s 26(2) in the Constitution 1996. See also Soobramoney, above, para 31.

193 Grootboom, above, para 35.

194 These views have been expressed by the UN Committee on Economic, Social and Cultural Rights. 
believe, is true for at least some who could benefit from the progressive stances taken by in particular the Constitutional Court. Without the scope and freedom given by the Constitution to do so, and without the determination to make these rights real and effective, little progress would have been made on the way of reconciling and reconstructing a much divided and unequal society.

\section{POSTSCRIPT}

In the recent unanimous judgment of the Constitutional Court written by the President of the Court and delivered after the writing of this contribution, Minister of Health $\mathcal{E}$ others $v$ Treatment Action Campaign \& others Case no CCT9/02 (judgment of the Constitutional Court, delivered on 5 July 2002), the Court upheld the principles developed in the Grootboom case. It stressed that socio-economic rights are justiciable (para 25), and reiterated that a purposive reading of the socio-economic rights enshrined in sections 26 and 27 of the Constitution (that is, access to adequate housing, access to health care services, including reproductive health care, access to social security) implies that these rights should not be construed as entitling everyone to demand that a minimum core be provided to them, but that:

[A]11 that is possible, and all that can be expected of the state, is that it act reasonably to provide access to the socio-economic rights identified in sections 26 and 27 on a progressive basis.

(paras 26-39, in particular para 35).

It emphasised again that:

[t]o be reasonable, measures cannot leave out of account the degree and extent of the denial of the right they endeavour to realise. Those whose needs are the most urgent and whose ability to enjoy all rights therefore is most in peril, must not be ignored by the measures aimed at achieving realisation of the right.

(para 68, quoting from the Grootboom case para 44).

The court refused to hold that to grant a mandatory order, and not merely a declaratory order, would amount to an unwarranted infringement of the separation of powers:

Where state policy is challenged as inconsistent with the Constitution, courts have to consider whether in formulating and implementing such policy the state has given effect to its constitutional obligations. If it should hold in any given case that the state has failed to do so, it is obliged by the Constitution to say so. In so far as that constitutes an intrusion into the domain of the executive, that is an intrusion mandated by the Constitution itself.

(para 99) 
This includes "...the power where it is appropriate to exercise some form of supervisory jurisdiction to ensure that the order is implemented". (para 104)

On the facts of the case it was declared that:

Sections 27(1) and (2) of the Constitution require the government to devise and implement within its available resources a comprehensive and co-ordinated programme to realise progressively the rights of pregnant women and their newborn children to have access to health services to combat mother-to-child transmission of HIV.

It was found that the policy for reducing the risk of mother-to-child transmission of HIV as formulated and implemented by government fell short of compliance with the constitutional requirements. (para 135)

The Government was consequentially ordered to remove without delay the restrictions that prevent nevirapine from being made available for the purpose of reducing the risk of mother-to-child transmission of HIV at public hospitals and clinics that are not research and training sites. The court ordered government to make the treatment available at hospitals and clinics when in the judgment of the attending medical practitioner acting in consultation with the medical superintendent of the facility concerned this is medically indicated, which shall if necessary include that the mother concerned has been appropriately tested and counselled. (para 135) The Government was also ordered to make provision if necessary for counsellors based at public hospitals; and to take reasonable measures to extend the testing and counselling facilities at hospitals and clinics throughout the public health sector to facilitate and expedite the use of nevirapine for the purpose of reducing the risk of mother-to-child transmission of HIV. (para 135) 
